\title{
Pertanggungjawaban Hukum Barang Aset Kantor Penghubung Kabupaten Buton di Kota Kendari
}

\author{
Legal Liability of Assets \\ Buton District Connection Officein Kendari City
}

\author{
Wahyu Prianto ${ }^{1}$ \\ ${ }^{1}$ Program Studi Ilmu Hukum, Universitas Nahdlatul Ulama Sulawesi Tenggara, Kendari \\ Email : Wahyuprianto11@gmail.com
}

\begin{abstract}
ABSTRAK
Pentingnya pengelolaan barang iventaris sebagai penunjang kinerja pelayanan kantor penghubung Kabupaten Buton, Namun yang terjadi pengadaan yang tidak sesuai dengan kebutuhan diakibatkan karena proses perencanaan yang kurang baik, perencanaan tidak dijalankan berdasarkan kebutuhan prioritas. Tujuan penelitian yaitu untuk mengetahui pertanggungjawaban barang milik daerah di Kantor Penghubung Kabupaten Buton di Kota Kendari dan juga mengetahui faktor-faktor yang mempengaruhi pertanggungjawaban terhadap barang milik daerah di Kantor Penghubung Kabupaten Buton di Kota Kendari. Jenis penelitian Yuridis Empiris dengan melihat pertanggungjawaban dari pengelolaan barang milik daerah. Kemudian melihat pengelolaan barang milik daerah di Kantor Penghubung Kabupaten Buton di Kota Kendari. Jenis dan sumber data primer dan data sekunder. Pengumpulan data melalui observasi dan wawancara yang dianalisis secara deskriptif kualitatif untuk menelaah data-data yang dideskripsikan untuk menjawab permasalahan. Hasil penelitian pertanggungjawaban hukum atas pengelolaan barang milik pemerintah di Kantor Penghubung Kabupaten Buton di Kota Kendari sangat tidak sesuai dengan ketentuan peraturan perundang-undangan, salah satunya karena barang milik daerah saat ini dapat sembarangan dipindah tangankan tanpa memenuhi persyaratan yang telah diatur dalam hukum yang mengatur tentang barang milik daerah.
\end{abstract}

Kata Kunci :Konsekuensi Hukum; Barang Aset; Kantor Penghubung

\begin{abstract}
The importance of managing inventory items as supporting the performance of the Buton Regency liaison office service, however, planning is not carried out based on priority needs. The purpose of the study is to determine the accountability of regional property at the Buton Regency Liaison Office in Kendari City and also to determine the factors that influence the accountability property at the Buton Regency Liaison Office in Kendari City. This type of empirical juridical by looking accountability of the management of regional property. Then look at the management of regional property at the Buton Regency liaison office in Kendari. Types and sources of primary and secondary data. Collecting data through observation and interviews which were analyzed descriptively qualitatively to examine described to answer the problem. The results of the study Legal accountability for the management of government property at the Buton Regency liaison office in Kendari is not in accordance with the provisions of the legislation, which is because current regional property can be arbitrarily transferred without fulfilling the requirements set out in the law governing property.
\end{abstract}

Keywords :Legal Consequences; Assets; Connection Officein 


\section{PENDAHULUAN}

Sejak reformasi keuangan negara bergulir, yang ditandai dengan terbitnya Undang-undang Nomor 17 Tahun 2003 tentang Keuangan Negara, Pemerintah Republik Indonesia telah membangun komitmen yang kuat untuk memenuhi prinsip-prinsip tata kelola pemerintahan yang baik (good governance) melalui pengelolaan keuangan yang sehat dan modern (sound and modern). Lingkup perubahan yang terjadi sangat mendasar dan bersifat menyeluruh, termasuk didalamnya adalah pengelolaan aset negara/daerah. International best practice memperlihatkan peran strategis pengelolaan aset negara/daerah sebagai salah satu indikator penting dalam pengelolaan anggaran negara/daerah dan upaya perwujudan akuntabilitas tata kelola suatu keuangan negara/daerah. ${ }^{1}$

Diterbitkannya Undang-undang Nomor 1 Tahun 2004 tentang Perbendaharaan Negara, menjadi titik perubahan paradigma pengelolaan aset negara/daerah, dari semula sebagai aset administrator menjadi aset manager. Hal ini diikuti dengan pembentukan Direktorat Jenderal Kekayaan Negara (DJKN) sebagai eselon satu di lingkungan Kementerian Keuangan yang memiliki fungsi kelembagaan untuk mengelola kekayaan negara/daerah, guna mendorong optimalisasi penerimaan,efisiensi pengeluaran, dan efektifitas pengelolaan aset negara/daerah dalam rangka mewujudkan good governance dan pengamanan fiscal sustainability. ${ }^{2}$

Pengelolaan aset negara/daerah di Indonesia, telah diterbitkan Peraturan Pemerintah Nomor 6 Tahun 2006 tentang Pengelolaan Barang Milik Negara/Daerah (BMN/D) yang diubah dengan Peraturan Pemerintah Nomor 38 Tahun 2008 tentang Pengelolaan BMN/D dengan beberapa aturan teknis, seperti Peraturan Menteri Keuangan (PMK) Nomor 96/PMK.06/2007 tentang Tata Cara Pelaksanaan Penggunaan, Pemanfaatan, Penghapusan, dan Pemindahtanganan BMN, PMK Nomor 97/PMK.06/2007 tentang Kodefikasi dan Penggolongan BMN, PMK Nomor 120/PMK.06/2007 tentang Penatausahaan BMN, dan PMK Nomor 2/PMK.06/2008 yang diubah dengan PMK Nomor179/PMK.06/2009 tentang Penilaian BMN, dan Peraturan Menteri Dalam Negeri Nomor 17 tahun 2007 tentang Pedoman Teknis Pengelolaan Barang Milik Daerah. ${ }^{3}$

Berdasarkan Pasal 4 Peraturan Menteri Dalam Negeri Nomor 17 tahun 2007 tentang Pedoman Teknis Pengelolaan Barang Milik Daerah disebutkan pada ayat (1) dan ayat (2), pada pelaksanaannya pengelolaan barang milik daerah yang meliputi beberapa aspek, belum sepenuhnya berjalan dengan baik hal ini dikarenakan pada praktiknya masih banyak terjadi kelemahan dan hambatan pada masing-masing pemerintahan daerah di Indonesia, diantaranya yaitu kurangnya kompetensi dan koordinasi antara pengelola keuangan dengan pengelola barang dimasing-masing Satuan Kerja Perangkat Daerah (SKPD) dalam bentuk laporan yang berkualitas, serta pengelolaan BMD yang belum berkembang dengan baik di lingkungan pemerintahan maupun di satuan kerja atau instansi, sehingga perlu menjadi perhatian bagi Pemerintah Daerah untuk meningkatkan kompetensi dari sumber daya manusia yang akan mengurus dan mengelola aset pemerintah dan diharapkan asetaset daerah mampu dioptimalkan penggunaan dan pemanfaatannya dalam menunjang kinerjanya, selain itu Dalam proses pengelolaan barang milik daerah pada sejumlah SKPD pemerintah Indonesia, terjadi ketidak sesuaian antara pengeluaran anggaran dengan peraturan perundang-undangan. ${ }^{4}$

Sejalan dengan apa yang telah diterangkan diatas, pada kenyataannya, masalah pengelolaan barang milik daerah masih diwarnai dengan beberapa permasalahan seperti yang terjadi pada pemerintah Kabupaten Buton, masalah yang kerap dihadapi dalam pengelolaan barang milik daerah/aset daerah.

Menjadi landasan penting seberapa pentingkah pengaturan barang inventaris milik daerah, menurut Dadang Solihin ada beberapa alasan mendasar yang menjadi alasan betapa pentingnya tata-kelola Barang Milik Daerah (BMD) antara lain untuk kejelasan status kepemilikan barang milik

\footnotetext{
${ }^{1}$ Widodo, Joko. 2001. Akuntabilitas dan Kontrol Birokrasi Pada Era Desentralisasi dan Otonomi Daerah. Surabaya: Insan Cendekia, hlm.75

${ }^{2}$ Ibid., hlm.79

${ }^{3}$ Ida Bagus Indra Mahardika.2016. PertanggungJawaban Hukum Terhadap Tata Pengelolaan Barang Milik Negara/Daerah Oleh Pejabat Pemerintah.Skripsi : Fakultas Hukum Udayana Denpasar, hlm. 23

${ }^{4}$ Ibid., hlm.24
} 
daerah, Iventarisasi kekayaan daerah dan masa pakai barang milik daerah, optimalisasi untuk penggunaan dan pemanfaatan pendapatan asli daerah, antisipasi barang milik daerah dalam fungsi pelayanan publik, pengaman barang daerah, dasar penyusunan neraca, serta kewajiban untuk melaporkan kondisi dan nilai barang milik daerah secara berkala. ${ }^{5}$

Kabupaten Buton sendiri sebagai kabupaten yang berada di kepulauan yang terpisah lautan dengan ibukota Provinsi Sulawesi Tenggara yakni Kota Kendari, menyadari dengan sepenuhnya bahwa betapa pentingnya keberadaan kantor penghubung yang berada di ibukota provinsi, demi menunjang pelayanan kepada masyarakat Kabupaten Buton yang memiliki kepentingan di Kota Kendari termasuk juga kinerja pemerintah Kabupaten Buton di Kota Kendari.

Kantor Penghubung Kabupaten Buton dibentuk berdasarkan pembaharuan atas undangundang yang sebelumnya, Peraturan Daerah Kabupaten Buton Nomor 4 Tahun 2011 tentang Organisasi dan Tata Kerja Inspektorat, Bappeda dan Lembaga Teknis Daerah Kabupaten Buton, Pada Bagian 16 Pasal 83, yang secara umum mempunyai tugas pokok yaitu membantu pemerintah daerah dalam penyelenggaraan pemerintahan di Kendari.

Pentingnya pengelolaan barang inventaris sebagai penunjang kinerja pelayanan Kantor Penghubung Kabupaten Buton menjadi hal yang mesti dipenuhi dan hal tersebut telah didasarkan pada Peraturan Daerah Kabupaten Buton Nomor 2 Tahun 2009 tentang Pengelolaan Barang Milik Daerah, hal mendasarnya ialah Barang Milik Daerah sebagai aset penunjang dalam rangka penyelenggaraan pemerintahan dan pelayanan masyarakat luas perlu dikelola dengan baik, benar, nyata, efektif, efisien, transparan, adil, dan akuntabel dalam pengelolaan inventarisasi barang milik daerah.

Berdasarkan observasi penulis, beberapa barang tidak ditemukan di dalam Kartu Inventaris Ruangan (KIR). Masalah lainnya adalah belum disampaikannya laporan barang secara semesteran untuk tiap periode oleh petugas yang berwenang sehingga sulit dipantau perkembangan barang, baik secara kualitas maupun kuantitas, Padahal Permendagri Nomor 17 tahun 2007 tentang Pedoman Teknis Pengelolaan Barang Milik Daerah menyebutkan bahwa pelaporan barang milik daerah yang dilakukan kuasa pengguna barang disampaikan setiap semesteran, tahunan, dalam proses penghapusan, seringkali terdapat barang atau aset yang sudah tidak layak pakai (rusak), akan tetapi pada data barang milik daerah yang dicatat belum dilakukan penghapusan, sehingga pada laporan keuangan dengan laporan aset perlu dilakukan rekonsiliasi.

Masih berdasarkan observasi penulis, pada proses pengadaan barang dan jasa aset daerah Kabupaten Buton, jika melihat pelaksanaannya dengan berdasarkan pada Peraturan Menteri Nomor 17 Tahun 2007 tentang Pedoman Teknis Pengelolaan Barang Milik Daerah menyebutkan, maka mengenai prosedur pengadaan, yaitu sebelum dilakukan pengadaan barang dan jasa, terlebih dahulu SKPD melakukan perencanaan, dengan mengajukan Rencana Kebutuhan Barang Milik Daerah (RKBMD) dan Rencana Kebutuhan Pemeliharaan Barang Milik Daerah (RKPBMD) sebagai dasar penyusunan Rencana Kerja Anggaran (RKA) kepada Dinas Pengelolaan Keuangan dan Aset Daerah, untuk kemudian dianalisis oleh tim asistensi anggaran dan tim asistensi dewan, agar mendapatkan persetujuan.

Namun yang terjadi saat ini, pengadaan yang tidak sesuai dengan kebutuhan hal ini diakibatkan karena proses perencanaan yang kurang baik, dimana perencanaan tidak dijalankan berdasarkan kebutuhan skala prioritas serta kecukupan anggaran yang tersedia. Sedangkan untuk melakukan pengadaan harus mempertimbangkan jumlah kebutuhan barang, ditetapkan dengan mempertimbangkan besaran organisasi atau jumlah pegawai dalam satu organisasi, beban tugas dan tanggung jawabnya, supaya tercapai prinsip efisiensi dan efektifitas dalam pengadaan barang sesuai dengan Bab IV Pengadaan, Pasal 11 Peraturan Menteri Dalam Negeri Nomor 17 tahun 2007 tentang Pedoman Teknis Pengelolaan Barang Milik Daerah yang menyebutkan bahwa : pengadaan barang milik daerah dilaksanakan berdasarkan prinsip-prinsip efisien, efektif, transparan dan terbuka, bersaing, adil/tidak diskriminatif dan akuntabel.

Penulis melihat salah satu faktor yang saat ini, cukup mempengaruhi pengadaan barang dan jasa aset pemerintah daerah Kabupaten Buton yakni belum dilakukannya tata kelola dan manajemen 
aset dengan baik, karena sebelum adanya pengadaan terlebih dahulu seharusnya dilakukan proses perencanaan untuk mengidentifikasi kesenjangan atau perbedaan antara aset-aset yang telah ada dan aset-aset prioritas utama yang dibutuhkan dalam penyelenggaraan tugas dan fungsi suatu SKPD.

Perencanaan juga mengidentifikasi aset-aset yang memerlukan penggantian, pembaruan atau perbaikan untuk memenuhi kebutuhan penyediaan pelayanan, Sehingga dengan belum berjalannya pengelolaan barang dan jasa aset Pemerintah Daerah Kabupaten Buton dengan baik, sebab ada beberapa barang yang diadakan seperti yang terjadi didalam Kantor Penghubung Kabupaten Buton di Kendari namun tidak digunakan karena tidak sesuai dengan kebutuhan/keperluan, disamping itu dalam pengadaan barang dan jasa aset pemerintah Kabupaten Buton sering diadakan dua kali berturut-turut sehingga bertumpuk dan tidak bermanfaat, salah satu penyebabnya akibat tidak adanya data inventaris barang sebelum dilakukan pengadaan sebagai acuan dalam mengadakan barang dan jasa aset pemerintah.

Berdasarkan hal tersebut, maka yang menjadi masalah dalam penelitian ini adalah bagaimanakah pertanggungjawaban hukum barang aset Kantor Penghubung Kabupaten Buton diKota Kendari.

\section{METODE PENELITIAN}

Penelitian ini adalah penelitian Yuridis empiris, Yaitu dengan menelaah peraturan Perundangundangan tentang kewenangan pemerintah daerah dalam pengadaan barang dan jasa milik daerah pada lingkup Pemerintah Daerah Kabupaten Buton, dan menelaah pelaksanaan kewenangan pemerintah daerah dalam pengadaan barang dan jasa milik daerah Kabupaten Buton Di Kota Kendari, adapun Jenis dan sumber data merupakan bahan utama yang diperlukan dalam penelitian ini antara laindata yang diperoleh dari secara langsung di lapangan melalui wawancara dengan para pejabat terkait atau pengamatan sendiri, dengan obyek yang akan diteliti dan juga termaksud data yang diperoleh secara tidak langsung, dalam hal ini diperoleh dari literatur-literatur kepustakaan, guna mendapatkan landasan teoritis berupa pendapat-pendapat, dokumen, ataupun bahan-bahan hukum lainnya, dan adapun upaya untuk dapat memperoleh validitas bahan hukum, sehingga akan diperoleh data yang akurat sebagai bahan kajian maka cara pengumpulan data dalam penelitian ini antara lain teknik observasi (pengamatan) yaitu mengadakan pengamatan langsung terhadap lokasilokasi penelitian.

Teknik interview yang digunakan adalah wawancara tertutup yaitu penelitian secara langsung mengadakan tanya jawab dengan responden, dimana wawancara tersebut dilakukan secara terarah dengan menggunakan daftar pertanyaan sebagai pedoman, dan teknik dokumentasi suatu cara pengumpulan bahan hukum dengan membaca dan mempelajari bahan-bahan bacaan yang berupa literatur, perundang-undangan, doktrin-doktrin dan sumber lain yang mempunyai relevansi dengan permasalahan, sehingga mendapatkan gambaran secara teoritis. Analisis Bahan Hukum (Informasi)yang berhasil dikumpulkan diolah secara sistematis, selanjutnya dilakukan analisis secara kualitatif yaitu meneliti, menelaah bahan-bahan hukum yang ada, serta disajikan dalam bentuk uraian secara deskriptis kualitatif untuk dapat menjawab rumusan masalah.

\section{HASIL DAN PEMBAHASAN}

Kantor Penghubung Kabupaten Buton melakukan penerimaan dan penyimpanan dari barang yang pada dasarnya dilaksanakan berita acara penerimaan yang bukukan dalam file komputer bendahara barang, telah sesuai dengan pasal 19 dan 20 Peraturan Daerah Nomor 2 Tahun 2009 tentang Pengelolaan Barang Milik Daerah Kabupaten Buton:

a. Penerimaan Pasal 19:

Barang yang telah diadakan, diterima oleh Penyimpan Barang untuk disimpan didalam gudang penyimpanan;

b. Penyimpanan Pasal 20

Penyimpan barang dilakukan dengan ketentuan sebagai berikut:

1) penyimpan barang hanya dapat menggudangkan barang pengadaan yang disertai dengan Surat Perintah Kerja/surat perjanjian/kontrak yang 
ditandatangani oleh pejabat yang berwenanng serta dokumen barang yang memuat macam/jenis, banyaknya, harga dan spesifikasi barang;

2) penyimpan barang dianggap sah apabila disertai berita acara penyerahan telah ditandatangani oleh Panitia Pemeriksa barang/pengurus barang dan Penyedia Barang;

3) apabila barang yang akan digudangkan, ternyata terdapat kekurangan atau syarat yang belum terpenuhi, barang tersebut dapat disimpan didalam gudang sebagai barang titipan sementara.

c. Penyaluran

Namun yang menjadi persoalan adalah penyaluran barang tersebut, banyak berita acara yang semestinya dipenuhi oleh bendahara barang, tidak dilaksanakan oleh bendahara barang tersebut, sebagaimana dalam Pasal 23 :

Dalam rangka penerimaan, penyimpanan dan penyaluran barang penyimpan barang menyiapkan dokumen sebagai berikut :

a. Keputusan Pembentukan Panitia Pemeriksa Barang;

b. Berita Acara Pemeriksaan Barang;

c. Beriata Acara Penerimaan Barang;

d. Buku Penerimaan Barang;

e. Buku Pengeluaran Barang;

f. Buku Barang Inventaris;

g. Buku Barang Pakai Habis;

h. Kartu Barang;

i. Kartu Persediaan Barang;

j. Laporan Semesteran dan Tahunan Tentang Penerimaan dan Pengeluran Barang Pakai Habis dan Barang Inventaris;

k. Bukti Pengambilan Barang Dari Gudang;

I. Berita Acara Penerimaan Terdapat Selisih;

m. Buat Pernyataan Penggantian Barang Sementara;

n. Berita Acara Pemeriksaan Barang Korban Bencana Alam dan Korban Bencana Kebakaran;

o. Surat Perintah Pengeluaran;

Khusus pada Kantor Penghubung Kabupaten Buton di Kendari, yang paling menjadi fokus adalah poin $\mathrm{H}$ yaitu kartu barang, sesuai pengamatan penulis serta didukung oleh keterangan Kepala Tata Usaha Kantor Penghubung Kabupaten Buton di Kendari yang menjelaskan bahwa :

"Barang yang keluar dari gudang atau yang akan disalurkan kepengguna itu memang harus didampingi kartu barang dan itu merupakan tanggungjawab dari bendahara gudang kenapa dia tidak mengeluarkan kartu barang atas barang yang dia sudah saluarkan ke unit kerja."

Fakta lain yang ditemukan oleh penulis pada saat pemeriksaan dari pihak Inspektorat dan Badan Pemeriksa Keuangan, fakta lapangan pada saat itu pertanggungjawaban bendahara gudang telah mengundurkan diri, informasi di lokasi penelitian itu dikarenakan pertanggungjawaban barang yang tidak diketahui keberadaannya, barang yang dikeluarkan tidak memenuhi syarat wajib sebagaimana diatur pada Pasal 23 Peraturan Daerah Nomor 2 Tahun 2009 tentang Pengelolaan Barang Milik Daerah Kabupaten Buton yakni dalam rangka penerimaan, penyimpanan dan penyaluran barang penyimpan barang menyiapkan beberapa dokumen diantaranya pada poin $\mathrm{H}$ menerangkan harus didampingi dengan kartu barang.

Hasil observasi di lokasi penelitian, penulis mendapatkan informasi bahwa praktek penyaluran barang atau dikeluarkannya barang tanpa didampingi beberapa berita acara dan kartu barang seperti disebutkan pada Pasal 23 tersebut telah berlangsung sejak lama, hal inilah yang menyebabkan terbukanya peluang untuk barang yang telah dikeluarkan tersebut diambil oleh oknum tidak bertanggungjawab, menjadi modus melegalkan barang-barang yang keluar dari gudang barang lalu disalurkan ke unit atau ruangan kerja masing-masing tanpa didampingi dengan kartu 
inventaris ruangan dan kartu inventaris barang, membuka peluang bagi oknum di ruangan tersebut melakukan tindakan untuk menguntungkan diri sendiri atas barang milik daerah.

Pada saat penulis menanyakan kepada bendahara barang, ia mengatakan bahwa :

"Mengenai barang yang keluar dari gudang barang yang tidak memiliki atau diampingi KIR itu pada dasarnya adalah persoalan yang mungkin sudah lama di tempat ini, oleh sebab itu maka seyokyanyatanggungjawap bendahara barang yang lama atau sebelumnya, dan bukan tangguangjawab bendahara barang saat ini atau yaitu saya sendiri, mungkin untuk pertanyaan seperti ini sebaiknya ditanyakan ke bendahara barang sebelumnya yaitu La Kaiman, dan saya sebagai bendahara barang yang baru, mengenai KIB dan KIR itu nanti saya pasti akan buat".

Menjadi penting bahwa implementasi dalam Pasal 23 tersebut dapat dilaksanakan secara penuh di Kantor Penghubung Kabupaten Buton Kota Kendari. Karena jika melihat fakta di lokasi penelitian secara tegas penulis menyimpulkan bahwa pihak terkait pada kantor penghubung Kabupaten Buton di Kendari menyimpang dari pasal tersebut.

1) Penatausahaan

Penatausahaan adalah rangkaian kegiatan yang meliputi pembukuan, inventarisasi dan pelaporan barang milik daerah sesuai dengan ketentuan yang berlaku.

Bagan 1 : Alur Penatausahaan Barang Milik Daerah

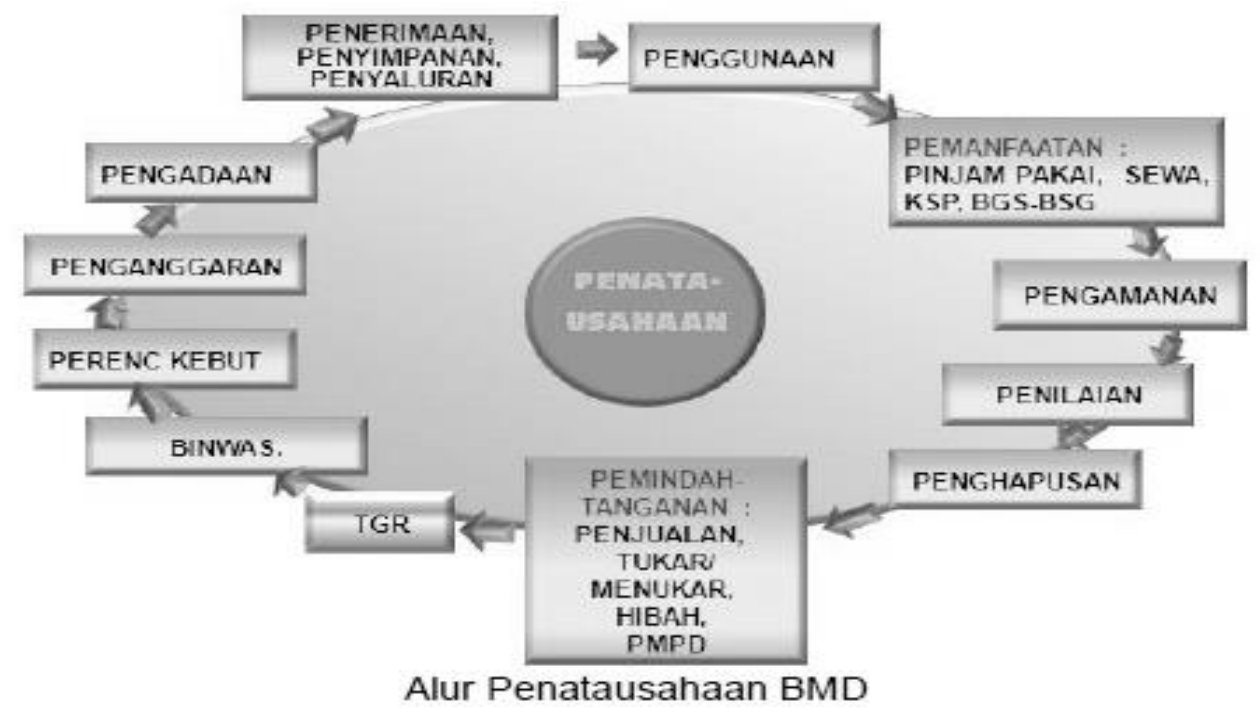

(Sumber : Diklat Teknis Substantif Spesiasialis Barang Milik Daerah)

Penatausahaan menjadi penting dalam pertanggungjawaban secara hukum atas penggunaan barang milik daerah, mengingat apa yang telah dipaparakan pada tahap penerimaan, penyimpanan, seta penyaluran yang tidak sesuai dengan ketententuan maka penatausahaan menjadi jawaban atas hal tersebut. ${ }^{6}$

a. Pembukuan sesuai Pasal 29 Peraturan Daerah Nomor 2 Tahun 2009 tentang Pengelolaan Barang Milik Daerah Kabupaten Buton :

1) Pengguna/Kuasa Pengguna Barang Milik Daerah harus melakukan pendaftaran dan pencatatan barang dalam Daftar Barang Pengguna (DBP)/Daftar Barang Kuasa Pengguna (DBKP);

2) Pengguna/Kuasa Pengguna dalam melaksanakan pendaftaran dan pencatatan sebagaimana dimaksud pada ayat (1) dilakukan sesuai format sebagai berikut :

\footnotetext{
${ }^{6}$ Sugiama, A Gima. 2013. Manajemen Aset Pariwisata: Guardaya Intimarta. hlm. 45
} 
b. Kartu Inventaris Barang (KIB) A Tanah ;

c. Kartu Inventaris Barang (KIB) B Peralatan Dan Mesin;

d. Kartu Inventaris Barang (KIB) C Gedung Dan Bangunan;

e. Kartu Inventaris Barang (KIB) D Jalan, Irigasi Dan Jaringan;

f. Kartu Inventaris Barang (KIB) E Aset Tetap Lainnya;

g. Kartu Inventaris Barang (KIB) F Konstruksi Dalam Pengerjaan;

h. Kartu Inventaris Ruangan (KIR);

i. Daftar Barang Inventaris;

j. Rekapitulasi Barang Inventaris;

k. Rekapitulasi Laporan Mutasi Barang;

Pembantu pengelola saat melakukan pendaftaran dan pencatatan barang sebagaimana dimaksud pada ayat (1) ke dalam Daftar Barang Milik Daerah (DBMD) harus melakukan koordinasi.

Menurut penulis Pasal 29 beserta Pasal 23 Peraturan Daearah Kabupaten Buton Nomor 2 Tahun 2009 tentang Pengelolaan Barang Milik Daerah adalah pasal yang tidak dipenuhi oleh pihak terkait dalam pengelolaan barang milik daerah di Kantor Penghubung Kabupaten Buton, sehingga menimbulkan situasi kacau-balau dalam proses pengiventarisasian barang milik daerah. Dasarnya adalah fakta lapangan yang ditemukan dan telah penulis paparkan sebelumnya.

Pelaporan sendiri mengacu pada Pasal 34 Peraturan Daearah Kabupaten Buton Nomor 2 Tahun 2009 tentang Pengelolaan Barang Milik Daerah :

(1) Pengelola, Pengguna dan Kuasa Pengguna serta Pembantu Pengelola harus membuat laporan barang inventaris milik daerah secara berjenjang kemudian oleh Pengelola membuat rekapitulasi dan laporan mutasi barang milik daerah kepala daerah;

(2) Pengguna barang menyampaikan laporan penggunaan barang semesteran, laporan tahunan dan 5 (lima) tahunan kepada kepala daerah melalui pengelola;

(3) Kuasa pengguna menyampaikan penggunaan barang smesteran, tahunan dan 5 (lima) tahunan kepada pengguna;

(4) Pembantu Pengelola menghimpun seluruh laporan penggunaan barang smesteran, tahunan dan 5 (lima) tahunan dari masing-masing SKPD dalam bentuk Daftar Inventaris beserta rekapitulasinya yang akan digunakan sebagai bahan penyusunan rencana daerah;

Dalam penatausahaan sesuai hasil observasi pada lokasi penelitian barang iventaris tersebut terbagi dua yakni barang habis pakai dan barang tidak habis pakai.

Barang habis pakai adalah barang-barang yang hanya dapat digunakan satu kali pemakaian. Artinya bahwa benda tidak selalu harus habis tanpa meninggalkan bekas dalam pemakaian. Sesuai data observasi pada Kantor Penghubung Kabupaten Buton di Kota Kendari, sebagai berikut :
i. Kertas;
ii. Bulpen;
iii. Stepless;
iv. Tinta Printer;
v. Stabilo;
vi. Spidol, ;
vii. Kertas Karbon;
viii. Stopmap;

Sedang barang tidak habis pakai pada Kantor Penghubung Kabupaten Buton di Kota Kendari ialah barang-barang yang dapat digunakan berulang kali dan tahan lama dalam permakaiannya pada pengadaan 2018. 
Tabel 1: Barang Habis Pakai Tahun 2018

\begin{tabular}{|l|l|c|}
\hline No. & \multicolumn{1}{|c|}{ Jenis Barang } & Jumlah \\
\hline 1 & Lemarai Dokumen & 24 \\
\hline 2 & Pendingin ruangan (AC) & 15 \\
\hline 3 & TV & 13 \\
\hline 4 & Meja Kerja & 40 \\
\hline 5 & Kursi Kerja & 35 \\
\hline 6 & Kompuiter \& Printer & 7 \\
\hline
\end{tabular}

(Sumber data : Kantor Penghubung Kab. Buton di Kota Kendari, 2018)

Dari kedua jenis barang iventaris tersebut yaitu habis pakai dan barang tidak habis pakai, dari hasil observasi pada Kantor Penghubung Kabupaten Buton di Kota Kendari, $80 \%$ barang tidak habis pakai sudah tidak tersisa tersebut dikarenakan kurang baiknya penatausahaan barang iventaris pada Kantor Penghubung Kabupaten Buton di Kota Kendari.

2) Inventarisasi

Mengenai iventarisasi di Kantor Penghubung Kabupaten Buton di Kota Kendari, seperti yang diungkapkan sebelumnya $80 \%$ barang tidak habis pakai sudah tidak tersisa, Berdasarkan apa yang ditemukan dilapangan bahwa buku induk itu kosong tidak terisi :

Tabel 2: contoh Buku Induk Iventaris

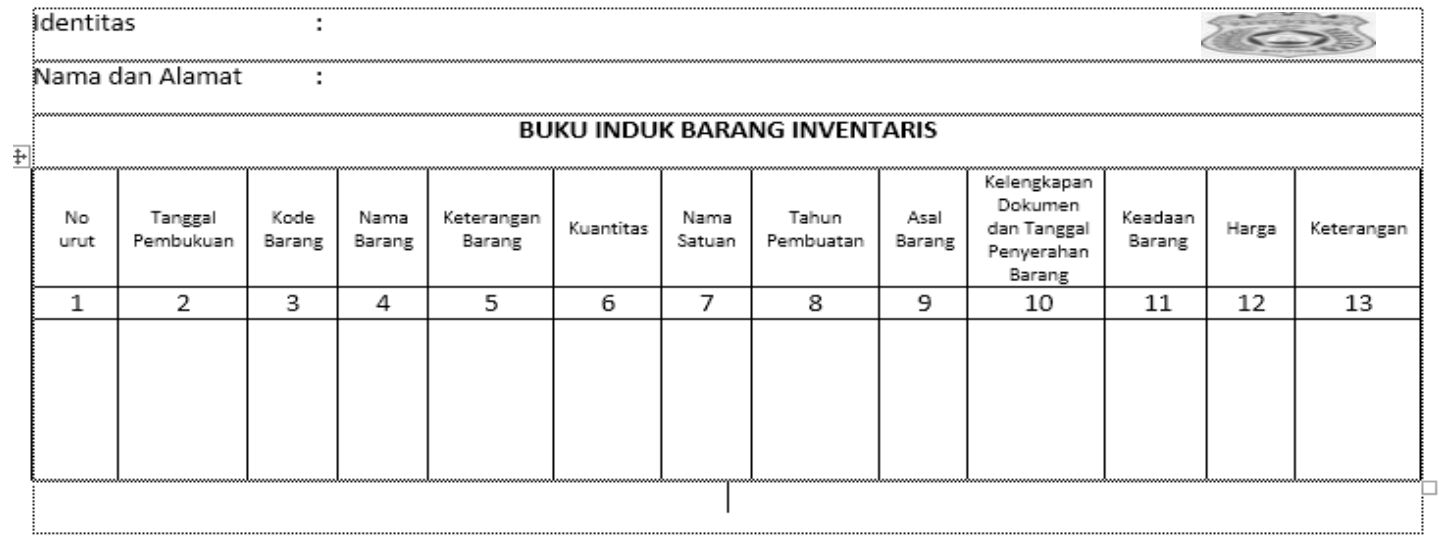

(Sebagai satu sampel ruangan Kepala Seksi Antar Lembaga)

Pada pengadaan barang Tahun 2018 diadakan sejumlah barang asset inventaris yang ada didalamnya dengan keterangan sebagai berikut :

Tabel 3: Pengadaan Barang Tahun 2018

\begin{tabular}{|c|l|c|c|c|}
\hline No & Nama Barang & Jumlah & $\begin{array}{c}\text { Terdaftar dalam } \\
\text { KIR }\end{array}$ & Memiliki KIB \\
\hline 1. & Kursi Tamu & 1 (Set/4 biji) & Tidak Terdaftar & Tidak ada \\
\hline 2. & Lemari Arsip & 1 Buah & Tidak Terdaftar & Tidak ada \\
\hline 3. & Meja Kerja & 6 Buah & Tidak Terdaftar & Tidak ada \\
\hline 4. & Komputer & 1 Buah & Tidak Terdaftar & Tidak ada \\
\hline 5. & Printer & 1 Buah & Tidak Terdaftar & Tidak ada \\
\hline
\end{tabular}

(Sumber data : Kantor Penghubung Kab. Buton di Kota Kendari. 2018.)

Berdasarkan data tersebut semua barang tidak memiliki KIB dan KIR, yang mana hal tersebut merupakan hal wajib dalam penginventarisasian barang aset daerah dan Inventarisasi barang milik daerah mesti dilakukan dengan : 
a) Pengelola dan pengguna barang milik daerah harus menyusun buku inventariasi yang mencatat semua barang milik daerah baik yang bergerak maupun yang tidak bergerak yang dilengkapi dengan data meliputi kode lokasi, kode barang, jenis, merek/type jumlah ukuran, harga, tahun perolehan sumber perolehan barang, kondisi barang dan sebagainya;

b) Pengelola dan pengguna barang milik daerah sebelum menyusun buku inventarisasi sebagaimana dimaksud pada ayat (1) terlebih dahulu melakukan sensus barang daerah yang dilaksanakan 5 (lima) tahun sekali;

c) Buku inventarisasi barang merupakan saldo barang milik daerah yang menjadi dasar bagi SKPD untuk melakukan daftar dan rekapitulasi laporan mutasi barang kepada Kepala Daerah melalui Pengelola.

Selain barang aset daerah, barang milik departemen lainnya seperti barang milik Pemerintah Pusat dan Pemerintah Provinsi yang dikelola/dipergunakan oleh Pemerintah Daerah dilakukan inventarisasi tersendiri terpisah dari buku inventrisasi Barang Milik Daerah

Kepala Daerah berwenang untuk melakukan pengendalian setiap mutasi perubahan penggunaan Barang Milik Daerah yang berada pada setiap SKPD atau perusahaan daerah Badan Usaha Milik Daerah dan Yayasan Milik Daerah.

Terkait identifikasi lapangan oleh penulis menanyakan kepada pihak terkait kali ini adalah bapak yang bertugas pada penyaluran barang ke ruangan-ruangan, menanyakan carut marutnya pengiventarisasi barang milik daerah, pertanyaan dispesifikan pada kenapa barang-barang aset daerah yang ada dalam ruangan seperti meja, lemari, hingga printer tidak memiliki kartu iventaris barang dan diruangan penempatan juga tidak memiliki kartu iventaris ruangan padahal hal ini adalah kewajiban sesuai Peraturan Daearah Kabupaten Buton Nomor 2 Tahun 2009 tentang Pengelolaan Barang Milik Daerah, memberikan keterangan pada saat itu sebagai berikut :

"Pembuatan kartu iventari ruangan memang pada saat ini belum kami buat, namun kami pasti akan membuatnya nanti, walaupu sebenarnya sudah harus dibuat dikarenakan penyaluran barang iventaris kantor itu sudah tersalurkan dan telah dugunakan, poinya adalah kami akan buat nanti"

Analisa penulis, hal ini hanya akal-akalan untuk mengelabui adminitrasi dalam pengiventarisasian barang milik daerah, karana dampak yang bisa ditimbulkan ialah oknum dapat saja mengambil barang yang di dalam ruangan tersebut sewaktu-waktu tanpa bisa dimintai pertanggungjawaban secara hukum karena barang tersebut tidak memiliki kartu inventaris barang dan di ruangan tersebut tidak ada kartu iventaris ruangan.

Berdasarkan hasil observasi juga memang pada dasarnya barang di Kantor Penghubung Kabupaten Buton di Kota Kendari, barang-barang begitu penting menggunakan KIB dan KIR seperti kertas, bulpen, stepless, tinta printer, stabilo, spidol, kertas karbon dan stopmap karena barangbarang tersebut ialah yang habis pakai, namun barang-barang lainnya seperti lemari dokumen sejumlah 24, pendingin ruangan (AC) sejumlah 15 unit, TV sejumlah 13 unit, meja kerja sejumlah 25 unit, kursi kerja sejumlah 25 unit, komputer dan printer sejumlah 7 unit tidak memiliki atau terdaftar dengan baik pada KIR dan KIB.

Gambar 2 : Kartu Iventaris Ruangan (KIR), yang masih kosong, tidak dimanfaatkan

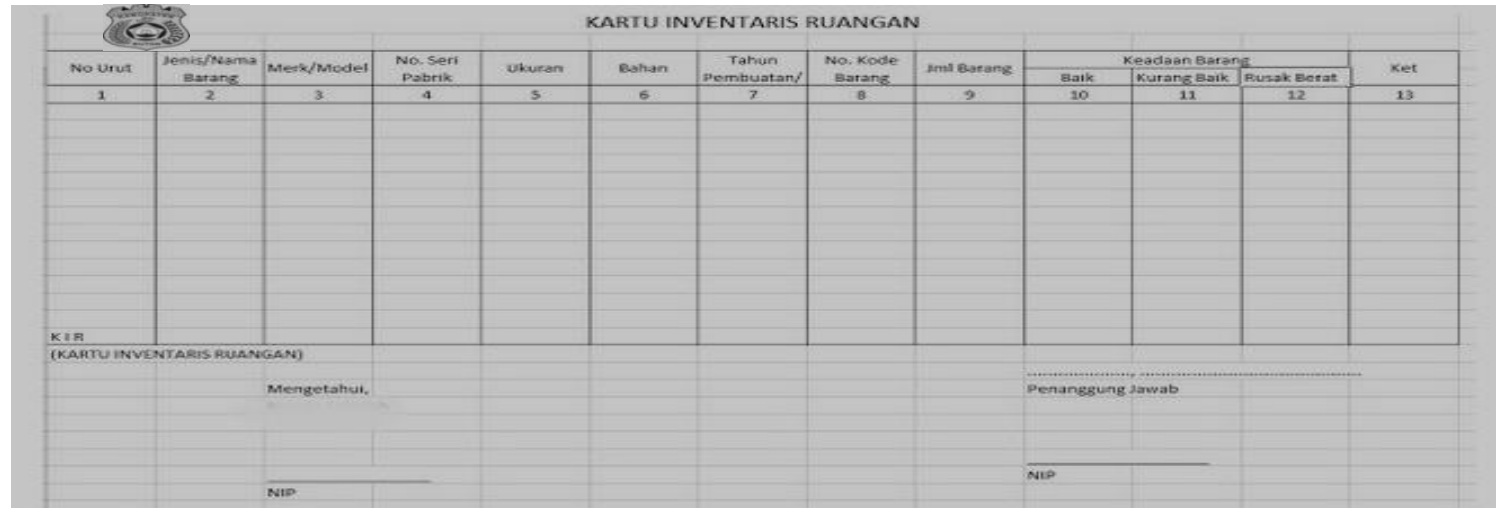

(Sumber : File Data Kantor Penghubung Kabupaten Buton di Kendari) 
Lalu menjadi pertanyaan besar ialah tentang pertanggungjawaban hukum terhadap hal tersebut, dalam Peraturan Daerah Kabupaten Buton Nomor 2 Tahun 2009 tentang Pengelolaan Barang Milik Daerah. Sebenarnya telah mengakomodasi hal tersebut, yakni tindakan hukum dilakukan terhadap barang inventaris yang bermasalah dengan cara :

1. Negosiasi (Musyawarah) untuk mencari penyelesaian;

2. Penerapan hukum;

Namun hal tersebut menurut penulis lagi-lagi menjadi tumpul karena tidak ada pihak yang mau menerapkanya sekalipun telah mengetauhi dan telah melihat secara jelas terhadap kacau balaunya pengiventarisasian barang milik daerah.

3) Pengamanan dan Pemeliharaan

a) Pengamanan

Setiap pengelola, pengguna dan kuasa pengguna harus melakukan pengendalian dan penertiban secara administrtif dan tindakan hukum terhadap semua barang milik daerah yang berada dalam penguasaannya sehingga dapat dimanfaatkan secara optimal serta terhindar dari penyerobotan, pengambilalihan atau klaim dari pihak lain; ${ }^{7}$

b) Pemeliharaan

Setiap pengelola, Pengguna dan Kuasa Pengguna harus melakukan tindakan-tindakan pemeliharaan terhadap barang milik daerah yang berada dalam penguasaannya tanpa merubah atau mengurangi bentuk atau kontruksi asal sehingga barang tersebut tetap memenuhi persyaratan untuk pemakaian maupun keindahan ${ }^{8}$.

Jika merujuk pada lokasi penelitian Kantor Penghubung Kabupaten Buton di Kota Kendari, mengenai pengamanan dan pemeliharaan, pada pengamanan ada beberapa maslah, seperti tingginya rasa memiliki barang oleh oknum pegawai terkadang mengamankan dalam arti membawa pulang barang-barang inventaris kantor seperti printer dan komputer, dan dari segi pemeliharaan juga barang inventaris di Kantor Penghubung Kabupaten Buton di Kota Kendari lebih kepada barang tidak habis pakai, seperti AC sejumlah 15 unit, TV sejumlah 13 unit, meja kerja sejumlah 25 unit, kursi kerja sejumlah 25 unit, dan komputer dan printer sejumlah 7 unit, hal tersebut tidak pernah dilakukan, bahkan terkadang seperti printer apabila rusak maka akan dibiarkan saja lalu nanti ada saja oknum yang mengambil keuntungan dari itu.

Sesuai Pasal 50 Peraturan Daerah Kabupaten Buton Nomor 2 Tahun 2009 tentang Pengelolaan Barang Milik Daerah. :

(1) Setiap Pengelola, Pengguna dan Kuasa Pengguna dalam melakukan pemeliharaan memperhatikan hal-hal sebagai berikut:

a. Pemeliharaan ringan dilakukan setiap hari kerja tanpa membebani anggaran;

b. Pemeliharaan sedang dilakukan dengan pembebanan biaya anggaran;

e. Pemeliharaan berat dilakukan perawatan sewaktu-waktu oleh tenaga ahli yang pelaksanaannya tidak dapat diduga sebelumnya tapi dapat diperkirakan kebutuhannya atas beban APBD;

(2) Barang Milik Daerah yang dilakukan pemeliharaan sebagaimana dimaksud pada ayat (1) hanyalah barang yang terdaftar dalam buku barang Inventaris:

Pada Pasal 50 Peraturan Daerah Kabupaten Buton Nomor 2 Tahun 2009 Tentang Pengelolaan Barang Milik Daerah pada poin 2 tersebut, maka sulit untuk melakukan pemeliharaan karen pemeliharaan harus yang terdaftar pada buku arang iventaris saja lalu bagaimana dengan observasi di Kantor Penghubung Kabupaten Buton di Kota Kendari yang sebgaian besar barangya tidak terdaftar di dalam buku barang iventaris.

\footnotetext{
${ }^{7}$ Rima Astari. 2013. Manajemen Pengelolaan Inventarisasi.Skripsi.Fakultas Ekonomi Universitas Negeri Semarang,hlm. 52

${ }^{8}$ Ibid.
} 
4) Pembinaan, Pengendalian dan Pengawasan

Pembinaan, Pengendalian Dan Pengawasan Pasal 99 Peraturan Daerah Nomor 2 tahun 2009 Tentang Pengelolaan Barang Milik Daerah :

(1) Pembinaan pengelolaan barang milik daerah dilakukan oleh menteri dalam negeri;

(2) Pengendalian Pengelolaan Barang Milik Daerah dilakukan oleh Kepala Daerah untuk menjamin terlaksananya rencana dan pekerjaan yang telah ditetapkan:

(3) Pengawasan yang meliputi pemantauan dan penertiban terhadap penggunaan, pemanfaatan, pemindahtanganan, penatausahaan, pemeliharaan dan pengamanan Barang Milik Daerah dilakukan oleh pengguna baran.

\section{Bagan 2 : Modul Pembinaan, Pengawasan dan Pengendalian}

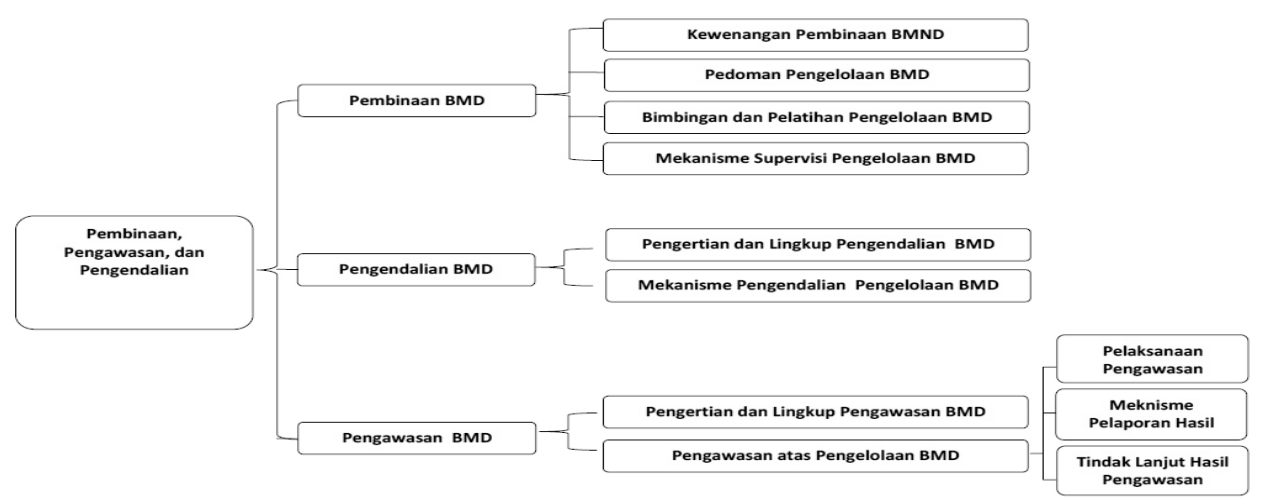

(Sumber : Diklat Teknis Substantif Spesiasialis Barang Milik Daerah)

Fakta lapangan bahwa pengawasan yang meliputi pemantauan dan penertiban terhadap penggunaan, pemanfaatan, pemindah tanganan, penatausahaan, pemeliharaan dan pengamanan barang milik daerah dilakukan oleh pengguna barang sedang tidak berjalan yang mengakibatkan amburadulnya pertanggungjwaban hukum dalam peiventarisasian barang milik daerah di kantor penghubungn Kabuapaten Buton. Hal tersebut terkait dengan pemeriksaan dari pihak Inspektorat dan BPK yang membuat bendahara barang sebelumnya memilih mengundurkan diri akibat tidak mau bertanggungjawab atas carut marutnya inventarisasi barang aset di Kantor Penghubung Kabupaten Buton di Kendari.

5) Penghapusan, Pemindahtanganan, Pelaporan dan Tuntutan Ganti Rugi Barang Milik Daerah Kantor Penghubung Kabupaten Buton di Kota Kendari

Pada dasarnya pertanggungjawaban hukum barang milik daerah di Kantor Penghubung Kabupaten Buton di Kendari telah diatur secara normatif, namun lagi-lagi oknum masih saja melakukan tindakan menguntukan diri sendiri atas barang tersebut dengan tidak sesuai norma yang ada. Mengenai penghapusan, pemindahtanganan, pelaporan dan tuntutan ganti rugi sesuai hasil observasi dan beberapa sumber menyampaikan bahwa jika barang inventaris tersebut ingin dijadikan milik pribadi ada prosedurnya yang harus dilakukan penghapusan, pemindahtanganan, pelaporan dan tuntutan ganti rugi, namun oknum pegawai lebih memilih melakukan pengusaan terhadap barang tersebut dengan tidak melakukan penghapusan, pemindahtanganan, pelaporan dan tuntutan ganti rugi bahkan lebih kepada pelanggaran terhadap Peraturan Daerah Kabupaten Buton Nomor 2 Tahun 2009 tentang Pengelolaan Barang Milik Daerah yang menerangkan tentang Penghapusan, Pemindahtanganan, Pelaporan dan Tuntutan Ganti Rugi Barang Milik Daerah, lebih rincinya sebagai berikut ${ }^{9}$

\section{a. Penghapusan}

Pengahapusan tidak dilakukan di lokasi penelitian namun banyak barang yang sudah tidak ada tidak didata sehingga penatausahaan dan inventarisasi barang aset kantor tidak teratur padahal pada Pasal 58 Peraturan Daerah Kabupaten Buton Nomor 2 Tahun 2009 tentang

${ }^{9}$ Ibid., hlm. 78 
Pengelolaan Barang Milik Daerah telah mengamanatkan perihal pengahapusan barang milik daerah.

Penghapusan barang milik Daerah meliputi:

a) Penghapusan dari Daftar Barang Pengguna dan/atau Kuasa Pengguna; dan

b) Penghapusan dari Daftar Barang Milik Daerah.

Selanjutnya Pasal 59 menyebutkan bahwa : Penghapusan barang milik daerah sebagaimana dilakukan dalam hal barang milik daerah dimaksud sudah tidak berada dalam penguasaan pengguna dan/atau kuasa pengguna yang dilaksanakan dengan Keputusan Pengelola atas nama kepala daerah.

\section{b. Pelaporan}

Mengenai pelaporan yang diperoleh dari bendahara barang Kantor Penghubung Kabupaten mengatakan kepada penulis bahwa :

"Pada saat pemeriksaan dari Inspektoran Republik Indonesia, lalu sebenarnya mereka telah mengetahui barang aset kantor tidak memiliki KIR dan KIB, namun pada saat pemerikasaan itu phak inpektorat menyarankan kepada bendahara bendaharan barang yang membuat KIB dan KIR susulan untuk memenuhi persyaratan bahwa kami melakukan iventarisasi barang sesuai aturan, padahal KIB dan KIR itu fiktif, karena seharusnya KIB dan KIR itu harusnya dibuat pada saat barang dikeluarkan dari gudang, bukan nanti setelah pemiriksaan baru dibuatkan".

Sedangkan mengenai Pelaporan Pasal 98 Peraturan Daerah Kabupaten Buton Nomor 2 Tahun 2009 tentang Pengelolaan Barang Milik Daerah, menyebutkan bahwa pemindahtanganan barang milik daerah yang dilakukan dengan cara penjualan, tukar menukar, hibah, dan penyertaan modal oleh Pemerintah Daerah dilaporkan kepada Menteri Dalam Negeri paling lama 15 (lima belas) hari setelah dikeluarkannya Keputusan penghapusan.

\section{c. Tuntutan Ganti Rugi}

Mengeni tuntutan ganti rugi sesuai hasil observasi, Kantor Penghubung Kabupaten Buton di Kota Kendari masih belum maksimal dalam melaksanakan pengiventarisasian barang milik daerah dan tidak sepenuhnya mengacu dan menjadikan panduan pada Peraturan Daerah Kabupaten Buton Nomor 2 Tahun 2009 tentang Pengelolaan Barang Milik Daerah. Sebagai penangungjawab tertingi maka penulis menganggap betapa pentingnya keterangan kepala kantor penghubung Kabupaten Buton terhadap hal ini dan berdasarkan hasil wawancara dengan Kepala Kantor Penghubung Kabupaten Buton di Kota Kendarimengatakan bahwa :

"Seluruh barang dan aset kantor penghubung yang ada di Kota Kendari seluruhnya diketahui oleh bendahara barang dan pertanggung jawaban oleh bendahara barang".

Dari hal tersebut analisa penulis bahwa jawaban dari kepala kantor tersebut hanyalah bentuk lempar tanggung jawab dari kacaunya pengiventarisasian barang milik daerah tersebut. Padahal berdasarkan pengamatan di lokasi penelitian hilangnya barang-barang milik daerah yang tidak memiliki kartu inventaris ruangan dan kartu inventaris barang itu menghilang pada saat setiap pergantian kepemimpinan, jelaslah keterkaitan pembiaran oleh kepala kantor yang semestinya sebagai pengawas dan pengendali namun terkesan membiarkan hal tersebut.

Sedangkan pada Pasal 103 Peraturan Daearah Kabupaten Buton Nomor 2 Tahun 2009 tentang Pengelolaan Barang Milik Daerah. :

(1) Setiap kerugian akibat pengelolaan barang Daerah akibat kelalaian, penyalahgunaan, pelanggaran hukum diselesaikan melalui tuntutan ganti rugi sesuai dengan peraturan perundang-undangan;

(2) Setiap pihak yang mengakibatkan kerugian daerah dapat dikenakan sanksi administrasi atau sanksi pidana ;

Sayangnya dalam Peraturan Daerah Kabupaten Buton Nomor 2 Tahun 2009 tidak diikuti dengan aturan pelakasanaan untuk menjelaskan sanksi admistrasi pada pasal 103 ayat (2) namun dalam Peraturan Menteri Dalam Negeri Nomor 17 Tahun 2007 tentang Pedoman Teknis Pengelolaan Barang Milik Daerah. Salah satu sanksi admistrasi ialah ganti rugi atau 
pemberhentian sementara dari jabatan. Sanksi admistrasi lainnya adalah salah satunya dengan cara memotong gaji, penghasilan yang bersangkutan namun jika pejabat dan pegawai di lingkungan Pemerintah Daerah terkait tindak pidana pelanggaran hukum sehingga merugikan daerah, maka yang bersangkutan dapat diberhentikan sementara oleh Bupati.

Berdasarkan pengamatan penulis adapun ketentuan-ketentuan yang mengatur tentang pertanggungjawaban hukum atas hilangnya barang milik daerah di Kantor Penghubung Kabupaten Buton, tidak sama sekali dilaksanakan, sehingga tidak ada sama sekali pertanggungjawaban bagi para oknum pejabat atau pegawai yang melakukan hal tersebut.

\section{KESIMPULAN}

Berdasarkan hasil penelitian yang sudah dibahas maka dapat diambil kesimpulan tentang pertanggungjawaban hukum terhadap aset barang kantor penghubung Kabupaten Buton di Kendari belum maksimal dilaksanakan, dimana yang menjadi dasar acuannya adalah ketentuan Peraturan Daerah Nomor 2 Tahun 2009 tentang Pengelolaan Barang Milik Daerah, dimana hal tersebut tidak dilaksanakan sepenuhnya, tidak adanya KIR dan KIB, mengakibatkan barang kantor mudah hilang atau tidak diketahui keberadaannya, jika mengacu kepada ketentuan maka pihak terkait harus melaporkan tentang kehilangan tersebut ke Bagian Pengelolaan Aset Pemerintah Daerah Buton. Namun hal itu juga tidak dilaksanakan, sehingga dengan demikian pimpinan dan seluruh pegawai di Kantor Penghubung Kabupaten Buton di Kendari harus menciptakan dan memelihara lingkungan organisasi yang menimbulkan perilaku positif dan mendukung terhadap pengendalian internal dan manajemen yang sehat agar terjadinya pentanggungjawaban hukum yang sehat dalam pengelolaan barang aset kantor Penghubung Kabupaten Buton. Selain itu semestinya ada sistem pengendalian Internal dalam lingkungan kerjanya yang lebih efektif terkait dengan unsur-unsur pengelolaan barang milik daerah. Upaya-upaya tersebut dapat dilakukan melalui, penegakan integritas dan nilai etika, komitmen terhadap kompetensi, kepemimpinan yang kondusif, pembentukan struktur organisasi yang sesuai dengan kebutuhan, pendelegasian wewenang dan tanggung jawab yang tepat, penyusunan dan penerapan kebijakan yang sehat tentang pembinaan sumber daya manusia.

\section{DAFTAR PUSTAKA}

Astawa I Gde Pantja, 2018, Problematika Hukum Otonomi Daerah Di Indonesia, P.T. Alumni, Bandung

Amiruddin, 2017, Korupsi Dalam Pengadaan Barang Dan Jasa, Genta Publising, Yogjakarta.

Andriani, Wiwik. Volume 5. 2016. Pengaruh Kapasitas Sumber Daya Manusia dan Pemanfaatan Teknologilnformasi Terhadap Keterandalan dan Ketepatwaktuan Laporan Keuangan Pemerintah Daerah : Studi pada Pemerintah Daerah Kab. Pesisir Selatan .Jurnal Riset Akuntansi Indonesia.

Crhistine, Amela E. 2014. Perbandingan PP 27 Tahun 2014 tentang Pengelolaan Barang Milik Negara/Daerah dengan PP 6 Tahun 2006 dan PP 38 Tahun 2008. Sekolah Tinggi Akuntansi Negara.

Dadang Sholihin. 2011. Penggunaan Aset Daerah.Evaluasi Kinerja Daerah, Jimbaran.

Ida Bagus Indra Mahardika.2016. Pertanggungjawaban Hukum Terhadap Tata Pengelolaan Barang Milik Negara/Daerah Oleh Pejabat Pemerintah.Skripsi : Fakultas Hukum Udayana Denpasar.

Hasfi, Nyemas. 2013. Pengelolaan Barang Milik Daerah (Suatu Studi Pada Dinas Pendapatan, Pengelolaan Keuangan dan Aset Kabupaten Sintang). Magister IImu Sosial Fakultas IImu Sosial dan Ilmu Politik Universitas Tanjungpura Pontianak. Jurnal Tesis PMIS UNTAN PSIAN Vol.1, No. 001. 
Juanda. 2008. Hukum Pemerintahan Daerah, P.T. Alumni, Bandung.

Mardiasmo, 2002.Otonomi Dan Manajemen Keuangan Daerah, Graha Ilmu, Yogyakarta.

Rima Astari. 2013. Manajemen Pengelolaan Inventarisasi. Skripsi. Fakultas Ekonomi Universitas Negeri Semarang.

Sugiama, A Gima. 2013. Manajemen Aset Pariwisata: Guardaya Intimarta

Soleh, Chabib dan Rochmansjah, Heru. 2010. Pengelolaan Keuangan Daerah dan Aset Daerah (Edisi kedua). Fokusmedia, Bandung.

Sunarno Siswanto, 2009. Hukum Pemerintahan Daerah Di Indonesia, Sinar Grafika

Syafie Inu Kencana, 2011.Manajemen Pemerintahan, Pustaka Reka Cipta, Bandung.

Undang-undang Nomor 23 Tahun 2014 tentang Pemerintahan Daerah

Peraturan Presiden Nomo 54 Tahun 2010 tentang Pengadaan Barang dan jasa

Peraturan Daerah Kabupaten Buton Nomor 2 Tahun 2009 tentang Pengelolaan Barang Milik Daerah

Peraturan Daerah Kabupaten Buton Nomor 4 Tahun 2011 tentang Organisasi dan Tata Kerja Inspektorat, Bappeda dan Lembaga Teknis DaerahKabupaten Buton 